\title{
Penetapan Daftar Pemilih Oleh Komisi Pemilihan Umum Sebagai Wujud Penguatan Sistem Demokrasi
}

\author{
Ahmad Zairudin, Universitas Jember, a.zairudin1988@gmail.com
}

\begin{abstract}
ABSTRAK
Pelaksanaan Pemilihan Umum (Pemilu) secara umum diatur dalam pasal 22E UUD 1945. Pemilu menjadi tolak ukur terhadap demokratisasi yang bermartabat dan sebagai salah satu sarana penyalur hak asasi warga negara yang sangat prinsipil. Hak memilih sebagai hak asasi manusia merupakan bagian penting dari prinsip kedaulatan rakyat yang tercermin dalam prinsip demokrasi dan menjadi landasan utama dalam bernegara yang dituangkan dalam konstitusi. Tujuan utama peletakan kedaulatan rakyat adalah penghargaan dan penilaian terhadap hak rakyat untuk memilih dan menentukan arah kehidupan bernegara dengan tujuan menjamin kesejahteraan bersama. Penetapan Daftar Pemilih Tetap (DPT) yang dilaksanakan olek Komisi Pemilihan Umum (KPU) merupakan bagian dari serangkaian sistem pemilu yan memiliki posisi penting dalam pelaksaan Pemilu. Dimana kewenangan KPU diatas dipertegas dalam Undang-Undang Pemilu UU N0 7 Tahun 2017.
\end{abstract}

KATA KUNCI: Pemilihan Umum, Rakyat, Demokrasi, dan Daftar Pemilih Tetap.

\section{LATAR BELAKANG}

Demokrasi adalah pemerintahan dari rakyat, oleh rakyat dan untuk rakyat. Oleh sebab itu kedaulatan tertinggi berada di tangan rakyat, karena 
pemerintah hanya sebagai penyelenggara pemerintahan. Dewasa ini Negara demokrasi dianggap sebagai sistem paling ideal didalam menjalankan pemerintahan. Pada abad ke-21 banyak negara-bangsa (nation state) yang asal mulanya menganut sistem negara yang ber-sifat monarki berubah menjadi negara demokratis. Sebab negara demokrasi adalah dimana rakyatlah yang harus diprioritaskan dalam mengambil kebijakan. Meskipun perubahan Negara-negara yang bersifat monarki harus mengalami proses demokratisasi setelah melakukan revolusi, namun rakyat tetap menghendaki keberadaan negara demokratis.

Indonesia yang menganut sebagai negara yang tergolong demokratis, tentu hak rakyat merupakan hal yang sangat fundamental untuk dijadikan landasan utama didalam mengambil kebijakan. Sebab sejatinya kekuasaan adalah milik rakyat. Didalam Undang-Undang Dasar Negara Republik Indonesia Tahun 1945 selanjutnya di sebut UUD NRI 1945 Bab I "Bentuk Dan Kedaulatan" Pasal 1 ayat (2) Kedaulatan berada di tangan rakyat dan dilaksanakan menurut Undang-Undang Dasar. Oleh karena itu dalam mengambil kebijakan, kepentingan rakyat harus dijadikan prioritas utama. rakyat yang merupakan pemegang kekuasaan tentu tidak ingin hanya menjadi boneka mainan yang dijadikan alat untuk memenuhi nafsu para pemburu kekuasaan.1

Dalam rangka meningkatkan kualitas daftar pemilih Pemilu, sumber data yang disusun oleh KPU untuk menyusun daftar pemilih, tidak hanya

\footnotetext{
${ }^{1}$ Faisal Rahman, Meneropong Integritas PenyelenggaraPemilu, Jurnal Ide, KPU, Volume 13, November, 2016, hlm. 9
} 
berdasarkan data penduduk potensial pemilih Pemilu (DP4) yang diperoleh kementerian dalam negeri, namun bisa juga menggunakan data Pemilu kepala daerah terakhir sebagai data pembandingnya. Sumber data tersebut diharapkan menghasilkan data yang akurat yang nantinya akan dimutahirkan oleh PPS dan Pantarlih. Menurut data KPU, daftar pemilih tetap DPT pada Pemilu 2019 sebanyak 192.828.520 Pemilih. Jumlah tersebut merupakan hasil rekapitulasi DPT hasil perbaikan Tahap 2. Sebanyak 190 juta di dalam negeri dan 2 juta diluar negeri. Berdasarkan data KPU tercatat jumlah pemilih laki laki sebanyak 96.271.476. sedangkan pemilih perempuan sebanyak 96.557.044. pemilih yang berada didalam negeri sebanyak 190.770.329. sementara diluar negeri 2.058.191 Pemilih.2

Hak konstitusional warga negara untuk memilih dan dipilih (rights to vote and right to be candidate) adalah hak yang dijamin oleh konstitusi, Undangundang dan konvensi International, sehingga pembatasan, penyimpangan, peniadaan dan penghapusan akan hak dimaksud merupakan pelanggaran terhadap hak asasi warga negara, dalam putusannya Mahkamah Konstitusi nomor 102/PUU-VII/2009, tentang pemilihan umum presiden dan wakil presiden.3 Selanjutnya hak hak warga negara untuk memilih ditetapkan sebagai hak asasi manusia dan hak konstitusional warga negara, (constitusional rights of citizen) sehingga oleh karenanya hak konstitusional tersebut di atas tidak boleh dihambat atau dihalangi oleh berbagai ketentuan dan proedur administrasi apapun yang mempersulit warga negara untuk

\footnotetext{
${ }^{2}$ https://www.nasional.tempo.co/amp/KPU diminta tetap mendata pemilih meski telah tetapkan dpt.

3 Putusan Mahkamah Konstitusi Nomor : 102/PUU-VII/2009, Bagian 3.13
} 
menggunakan hak pilihnya. Oleh karenanya penetapan pemilih oleh komisi pemilihan umum merupakan ujung tombak dalam menguatkan sistem demokrasi kita, ketentuan yang mengharuskan seseorang warga negara terdaftar sebagai pemilih dalam daftar pemilih tetap (DPT), lebih merupakan prosedur administratif dan tidak boleh menegasikan hal hal yang bersifat substansial yaitu hak warga negara untuk memilih (right to vote) dalam pemilihan Umum.

Hak memilih sebagai hak asasi manusia merupakan bagian penting dari prinsip kedaulatan rakyat yang tercermin dalam prinsip demokrasi dan menjadi landasan utama dalam bernegara yang dituangkan dalam konstitusi. Tujuan utama pelatakan kedaulatan rakyat adalah penghargaan dan penilaian terhadap hak rakyat untuk memilih dan menetukan arah kehidupan kenegaraan yang dapat menjamin kesejahteraan bersama. Penyelenggaraan Pemilu yang berintegritas (election with Integrity) yaitu bukan hanya sekedar Pemilu yang formalistik dan prosedural formal, tetapi Pemilu yang dilaksanakan secara demokratis dan berkeadapan dengan melibatkan langsung rakyat sebagai subjek dari pemilihan umum tersebut.

Berdasarkan latar belakang inilah diangkat Masalah tentang : Penetapan Pemilih Oleh Komisi Pemilihan Umum Sebagai Wujud Penguatan Sistem Demokrasi. Dengan Pertanyaan Penelitian Pertama, Bagaimana Kedudukan Komisi Pemilihan Umum dalam menjalankan Tugas dan Kewenangannya dalam upaya meningkatkan pemilih dan menciptkan Pemilu demokratis? dan Kedua, Apakah Penetapan Daftar Pemilih oleh Komisi Pemilihan Umum dapat menguatkan sistem demokrasi di Indonesia? 


\section{PEMBAHASAN}

\section{A. Kedudukan Komisi Pemilihan Umum dalam Menjalankan Tugas Dan \\ Fungsi Sebagai Upaya Meningkatkan Pemilih Dan Menciptakan Pemilu}

\section{Demokratis.}

Dalam suatu negara kecil yang jumlah penduduknya sedikit dan wilayahnya tidak terlalu luas, kedaulatan rakyat seperti diatas tidak dapat berjalan dengan semurni murninya. Apalagi dalam negara modern seperti sekarang, dimana jumlah penduduk sudah semakin banyak, dan wilayahnya sudah semakin luas, kiranya tidak mungkin meminta pendapat rakyat seorang demi seorang dalam menenentukan jalannya sistem pemerintahan, di tambah lagi pada masyarakat modern sekarang ini, spesialisasi sudah semakin tajam dan tingkat kecerdasan rakyat tidak sama. Hal ini yang menyebabkan kedaulatan rakyat tidak mungkin dapat dilakukan secara murni, dan keadaan menghendaki bahwa kedaulatan rakyat itu dilaksanakan dengan perwakilan. Dalam kedaulatan rakyat dengan perwakilan atau demokrasi dengan perwakilan (representatif democrazy) atau demokrasi tidak langsung (indirect democrazy), yang menjalankan kedaulatan itu adalah wakil wakil rakyat. Wakil rakyat tersebut bertindak atas nama rakyat dan wakil-wakil rakyat tersebutlah yang menentukan corak dan cara pemerintahan, serta tujuan apa yang hendak dicapai baik dalam waktu yang relatif pendek maupun dalam jangka waktu yang panjang.4 agar wakil-wakil rakyat tersebut benar-benar dapat bertindak atas nama rakyat, maka wakil-wakil rakyat tersebut harus ditentukan sendiri oleh rakyat. dalam menentukan ini biasa dipergunakan lembaga pemilihan umum. Jadi pemilihan umum tidak lain adalah suatu cara

\footnotetext{
${ }^{4}$ Moh kusnadi, Harmaily Ibrahim, Hukum Tatanegara Indonesia, CV Sinar Bakti, Jakarta 1988, hlm. 329
} 
untuk memilih wakil-wakil rakyat baik itu eksekutif maupun legislatif. Karenanya bagi suatu negara yang menyebut dirinya sebagai negara demokrasi pemilihan umum harus dilaksanakan dalam waktu-waktu tertentu. Karena pendapat rakyat tidak akan selalu sama dalam waktu yang panjang. Setelah dalam jangka waktu tertentu pendapat rakyat akan berubah, oleh karena itu pemilihan umum harus dilaksanakan dalam waktu-waktu tertentu.

Pemilihan umum adalah hak asazi bagi warga negara yang sangat prinsipil. Karena dalam rangka pelaksanaan hak asasi adalah suatu keharusan bagi pemerintah untuk melaksanakan pemilihan umum. Sesuai dengan azas bahwa rakyatlah yang berdaulat. Maka semuanya itu harus dikembalikan kepada rakyat untuk menentukannya. Adalah suatu pelanggaran terhadap hak asazi manusia apabila pemerintah tidak mengadakan pemilihan umum atau memeperlambat pemilihan umum tanpa persetujuan dari wakil-wakil rakyat. akan timbul suatu keraguan, apabila suatu pemerintahan menyatakan dirinya sebagai pemerintahan dari rakyat, padahal pembentukannya tidak didasarkan pada hasil pemilihan umum dengan perkataan lain, apabila pemerintahan menyatakan dirinya sebagai pemerintahan dari rakyat, maka hal itu harus sesuai dengan hasil pemilihan umum.

Sejalan hal tersebut International Comission Of Jurist dalam konfrensinya di Bangkok5 pada tahun 1965, memberikan definisi tentang pemerintahan dengan perwakilan atau representatif goverment sebagai, A goverment deriving its power and auotority are exercised through representatif freely chosen and responsible to them, dan untuk adanya suatu representatif goverment under the rule of law, konfrensi itu menetapkan salah satu syarat

\footnotetext{
${ }^{5} \mathrm{Ibid}, \mathrm{hlm} .330$
} 
adanya pemilihan yang bebas. Karena itulah pemilihan umum adalah syarat mutlat bagi negara demokrasi, untuk melaksanakan kedaulatan rakyat.

Pemilihan umum di Indonesia yang dilaksanakan secara langsung oleh rakyat merupakan sarana perwujudan kedaulatan rakyat guna menghasilkan pemerintahan negara yang demokratis berdasarkan pancasila dan UUD 1945. Penyelenggaraan pemilihan umum secara langsung, umum, bebas, jujur dan adil dapat terwujud apabila dilaksanakan oleh penyelenggara pemilihan umum yang mempunyai integritas, profesionalitas dan akuntabilitas.6

Undang-Undang Dasar Negara Republik Indonesia 1945 menyatakan bahwa pemilihan umum diselenggarakan oleh suatu komisi pemilihan umum yang bersifat nasional, tetap dan mandiri. Amanat konstitusi tersebut untuk memenuhi tuntutan perkembangan kehidupan politik, dinamika masyarakat, dan perkembangan demokrasi yang sejalan dengan pertumbuhan kehidupan berbangsa dan bernegara. Disamping itu negara Indonesia yang luas dengan jumlah penduduk yang sangat besar dan menyebar diseluruh nusantara dan memiliki kompleksitas nasional menuntut penyelenggara pemilihan umum yang profesional serta memiliki kredibilitas yang dapat dipertanggung jawabkan.

Penyempurnaan terhadap ketentuan peraturan perundang-undangan yang mengatur penyelenggara pemilihan umum dimaksudkan untuk lebih meningkatkan fungsi perencanaan, pengawasan dan evaluasi penyelenggaraan pemilihan umum. Oleh karena itu diperlukan satu undangundang yang mengatur tentang penyelenggaraan pemilihan umum.

\footnotetext{
6 Ibramsyah Amirudin, Kedudukan KPU Dalam Struktur Ketatanegaraan Republik Indonesia Pasca Amandemen UUD 1945, Laksbang Mediatama, Yogyakarta, 2008, hlm. 1
} 


\section{B. Tujuan Dilaksanakannya Pemilihan Umum Di Indonesia}

Idealisme penyelenggara pemilihan umum sebagaimana di amanatkan UUD 1945 sesungguhnya terkait dengan gagasan yang kompleks, yang mencakup upaya menjamin tercapainya tujuan, sekaligus dengan mewujudkan proses yang jujur dan adil. Komisi Pemilihan Umum (KPU) yang diidealkan tersebut terkait dengan tugas yang terakhir, yaitu sebagaimana kontestasi politik menemukan solusi yang jujur dan adil berdasarkan kedaulatan rakyat. penyelenggara pemilihan umum pada umumnya harus mampu menggabungkan antara tuntutan purpose based order dan rule based order sekaligus. Ini tentu membutuhkan keahlian dan terkait dengan aspek-aspek tekhnis yang tidak sederhana.

Begitu mulia tugas komisi pemilihan umum sebagai penyelenggara pemilihan umum yang langsung, umum, bebas, jujur, rahasia, dan adil demi terpilihnya wakil rakyat, presiden dan wakil presiden dan dewan perwakilan daerah, serta untuk membentuk pemerintahan yang demokratis, kuat dan didukung oleh rakyat dalam rangkan mewujudkan tujuan nasional sebagaimana undang-undang dasar 1945. Akan tetapi disisi lain, dibalik tugas mulia tersebut diperlukan kejelasan tentang dimana letak dan kedudukan komisi pemilihan umum (KPU) dalam struktur sistem ketatanegaraan republik indonesia pasca amandemen UUD 1945, serta bagaimana tugas, kedudukan, fungsi dan wewenang yang dimiliki oleh kmisi pemilihan umum, serta kendala yuridis dan teknis yang dihadapi oleh KPU dalam penyelenggaran pemilihan umum khususnya dalam menetapkan pemilih untuk mewujudkan sistem demokrasi. 


\section{Sistem Pemiliban Umum di Indonesia}

Sistem Pemilu merupakan hal utama dalam melaksanakan pemilihan umum legislatif, karena sistem Pemilu akan sangat berpengaruh dengan tahapan dan pelaksanaan Pemilu selanjutnya. Begitu juga sistem Pemilu akan menentukan demokratis dan tidaknya Pemilu dilaksanakan. Setiap sistem Pemilu didasarkan pada nilai-nilai tertentu, dan masing-masing memiliki beberapa keuntungan dan kerugian. Sebenarnya tidak ada sistem Pemilu ideal yang cocok di negara manapun, tetapi semua sistem itu memang mempunyai satu hal yang sama yaitu suatu proses pengembangan atau reformasi sistem Pemilu agar Pemilu mempunyai legitimasi dan demokratis. Setidak-tidaknya terdapat dua fungsi sistem pemilihan umum, pertama sebagai prosedur dan mikanisme konfersi suara pemilih (votes) menjadi kursi (Seats) penyelenggaraan negara lembaga legislatif dan atau lembaga eksekutif baik pada tingkat nasional maupun daerah. Prosedur mekanis inilah yang biasa disebut proses penyelenggaraan tahapan Pemilu. Untuk membedakan Pemilu authoritarian dari Pemilu demokratik, maka negara demokrasi menyusun undang-undang pemilihan umum yang pada dasarnya merupakan penjabaran prinsip-prinsip demokrasi. Seperti asas-asas Pemilu, Pemilu berintegritas, dan Pemilu berkeadilan akan dapat dirumuskan sejumlah parameter untuk proses penyelenggaraan Pemilu yang demokratik.7

Kedua, sebagai instrumen untuk membangun sistem politik demokrasi, yaitu melalui konsekuensi setiap unsur sistem pemilihan umum terhadap berbagai aspek sistem politik demokrasi. Sistem Pemilu terdiri atas enam unsur, dan empat diantaranya merupakan unsur mutlak dan dua unsur pilihan. Keempat unsur mutlak tersebut adalah Besaran Daerah Pemilihan, Peserta dan Pola

\footnotetext{
${ }^{7}$ Indra Pahlevi, Sistem Pemilu di indonesia antara Proporsional dan mayoritarian, P3DI dan Azza Grafika, Jakarta 2015, hlm. 3-4
} 
Pencalonan, Model Penyuaraan, dan Formula Pemilihan. Keempatnya disebut sebagai unsur mutlak karena tanpa salah satu dari keempat unsur ini ketiga unsur lain tidak akan mampu mengkonversi suara pemilih menjadi kursi. Dua unsur pilihan, yaitu ambang-batas perwakilan dan waktu penyelenggaraan berbagai jenis Pemilu, dikategorikan sebagai pilihan karena (1) keempat unsur sistem pemilihan umum lainnya masih mampu mengkonversi suara pemilih menjadi kursi dan (2) salah satu atau keduanya akan digunakan untuk mencapai tujuan lain yang tidak dapat dicapai dengan unsur sistem pemilihan umum lainnya.

Pada intinya, sistem proporsional menghendaki bahwa jumlah wakil rakyat yang duduk di lembaga perwakilan rakyat merupakan potret statistik penduduk. Artinya ada korelasi antara proporsi jumlah penduduk dan wakil yang duduk di lembaga perwakilan. Sementara sistem distrik pada asasnya menegaskan mandat wakil rakyat atas prinsip One Man One Vote. Dihubungkan dengan sistem kepartaian, sistem proporsional dipandang memiliki proteksi yang kuat untuk memelihara kemajemukan atau jumlah partai politik yang banyak karena perlakuan bahwa tidak ada suara yang tidak sah dan ada kemungkinan tiap- tiap partai politik di suatu daerah pemilihan mampu menempatkan wakilnya di lembaga perwakilan, beberapa pun jumlahnya. Sementara sistem distrik menegasikan hal itu karena the winners takes all, artinya sebuah mayoritas sederhana perolehan suara akan menyebabkan hanya satu partai politik yang mampu menempatkan wakilnya di lembaga perwakilan rakyat. Dengan sistem ini, sudah pasti banyak suara yang hangus dan pastinya akan menyebabkan partai politik mau tidak mau harus berkoalisi daripada tidak mempunyai wakil sama sekali.8

\footnotetext{
8 Aminah, Analisis Penerapan Sistem Proposional Dan Sistem Distrik Dalam Pemilihan Umum Untuk Penyedederhanaan Sistem Kepartaian Di Indonesia Ditinjau Dari Asas Negara Hukum, Jurnal Yustisia Volume 1, Nomor 2, Agustus 2012, hlm 2
} 
D. Faktor Pendukung dan Penghambat Verifikasi Daftar Pemilib Tetap (DPT)

Faktor pendukung ini adalah pelibatan peran masyarakat dalam tahapan penyusunan pemilih dalam pemilihan umum sangatlah penting. Hal tersebut mendukung suksesnya proses penyusunan data pemilih yang akurat dan akuntabel. Keterlibatan masyarakat dalam pemutkhiran data pemilih terutaman dalam memberikan masukan atau koreksi terhadap data pemilih yang telah di susun oleh PPS dimana sangat mungkin terjadi ketidak akuratan data akibat kurang telitinya petugas dalam penyusunan data pemilih dapat dibedakan menjadi dua.

Pertama, masyarakat dapat terlibat secara aktif dalam pelaksanaan pemutakhiran data pemilih dalam pemilihan umum dengan melibatkan diri untuk menjadi penyelengara pemilihan umumdi masing-masing tingkat mulai dari KPU sampai kepada jajaran paling bawah di lapangan yaitu KPPS. Dengan terlibat secara langsung tentu akan dapat secara aktif dan continue memberikan kontribusi yang positif terhadap kualitas data yang disusun KPU.

Kedua, keterlibatan masyarakat secara tidak langsung dalam tahapan pemutakhiran data pemilih, artinya masyakat dapat memberikan masukan atau koreksi terhadap data pemilih jika ditemukan ketidak cocokan atau ketidak sesuaian data yang telah disusun. Masukan serta koreksi terhadap data pemilih demi peningkatan kualitas data pemilih inilah yang menjadi tujuan utama dalam memverifikasi data pemilih. Fungsi pengawasan secara tidak langsung oleh masyarakat ini sangat di perlukanoleh penyelenggara dalam setiap tahapan penyusunan data pemilih. 
Sedangkan faktor penghambatnya, pertama, kurang tersedianya sumber daya manusia (SDM), merupakan salah satu faktor utama dari pelaksanaan verifikasi daftar pemilih tetap (DPT) tersebut akan berjalan dengan baik atau tidak baik. Sehingga dengan managemen SDM yang kurang maksimal akan menjadi faktor penghambat dalam penyusunan daftar pemilih tetap (DPT). Managemen SDM dapat di artikan sebagai pendayagunaan sumber daya manusia dalam organisasi yang dilakukan melalui fungsi-fungsi perencanaan seperti, rekrutmen, seleksi dan pengembangan sumber daya manusia itu sendiri.

Suatu kebijakan akan dapat terlaksana dengan baikjika di dukung oleh sumber daya manusia yang memadai (berkualitas). Karena suatu kebijakan jika tidak didukung dengan tenaga pelaksana yang terampil dan mumpuni dapat di pastikan kebijkan tersebut tidak akan terlaksana dengan baik sesuai tujuan yang telah ditetapkan dalam hal ini support terhadap pendataan atau verifikasi pemlih.

Kedua, belum maksimalnya pemanfaatan tekhnologi dalam sistem pengelolaan data pemilih. Keunggulan dari integrasi sistem ini adalah membaiknya suatu arus informasi dalam sebuah organisasi seperti KPU. Sistem informasi yang ada di KPU masih belum sepenuhnya berjalan dengan baik, sehinggapelaksanaan sistem informasi yang kurang baik dapat menghambat pendataan atau verifikasi pemilih.

Ketiga, dukungan anggaran pelaksana lapangan yang belum memadai. Kondisi lapangan banyak kendala yang sering dialami petugas, ketika petugas lapangan melakukan pendataan Dor to dor dengan bekerja ekstra penh waktu diamana pendataan lapangan telah ditetapkan selama 30 hari tersebut harus diselesaikan, namun disisi lain honor atau gaji petugas lapangan jauh dari kata layak, oleh karena itu penting kiranya honror tersebut di 
proposionalkan dengan beban kerj petugas. Jika hal tersebut tidak segera dibenahi, ditakutkan dapat mengganggu kinerja petugas pemutakhiran data pemilih di lapangan.

Selain hal di atas yang perlu di perhatikan dengan serius adalah, penguatan kelembagaan penyelenggara Pemilu. Pengalaman di sejumlah daerah tidak berkualitasnya proses penyelenggaraan Pemilu seperti pemutakhiran data pemilih disebabkan karena belum profesionalnya penyelenggara Pemilu itu sendiri terutama pada level panitia ad ho. Penyelenggara pada level ini yaitu, PPK, PPS, dan KPPS terindikasi banyak yang berstatus PNS dan mekanisme perekrutan tidak jarang dilakukan dengan melibatkan rekomendasi aparat desa, sehingga begitu mudah di intervensi oleh kekuatan politik yang sedang berkompetisi.

\section{E. Penguatan Sistem Dengan Penetapan Daftar Pemilih Oleh KPU sebagai}

\section{Wujud Penguatan Demokrasi.}

DPT sangat penting bagi usaha membangun pemilu yang demokratis. DPT menjadi basis partisipasi politik warga dalam pemilu, partisipasi politik memiliki peran penting bagi pembangunan politik demokrasi di setiap negara. Dalam konteks pemilu, voters turn out dari partisipasi warga menjadi basis dukungan terhadap kekuasaan yang absah melalui kompetisi pemilu di antara para peserta. oleh karena itu DPT bermasalah menjadi celah untuk tindakan penggelembungan suara atau munculnya suara palsu. Tindakan ini bisa menguntungkan paslon atau partai tertentu dan sebaliknya merugikan bagi paslon atau partai lainnya sehinga cita-cita dari pelaksanaan pemilu yang denokratis terderai. Peluang ini semakin crucial ketika pemilu 2019 diagendakan serentak pelaksanaannya (konkuren) di mana setiap pemiilih 
akan memperoleh empat lembar surat suara untuk dicoblos (Pemilu Presiden, pemilu anggota DPR, pemilu anggota DPD, dan Pemilu anggota DPRD). Dalam kurun waktu 2 bulan tambahan bagi usaha perbaikan DPT, basis administrasi dan politik partisipasi warga diharapkan bisa lebih dijamin. Masyarakat yang berhak memilih, tetapi belum masuk dalam DPT agar mendaftarkan diri ke petugas KPPS di kelurahan atau desa.

KPU harus bisa menguatkan terkait sistem data pemilih (Sidalih) untuk dapat menghindarkan DPT ganda. Tetapi kenyataannya, temuan data pemilih ganda tidak terlepas dari persoalan Sidalih KPU. Penguatan kapasitas Sidalih bersifat strategis, karena berpengaruh terhadap partisipasi politik warga untuk menggunakan hak pilihnya. Penggunaan hak pilih tidak terlepas dari prosedur pendaftarannya. Di Indonesia, pendaftaran pemilih masih bersifat pasif, di mana petugas pemutakhiran pemilih yang harus mendatangi dan mendata penduduk, melalui koordinasi dengan RW dan RT. Agenda solusi kelembagaan ini penting menjawab kekhawatiran potensi suara yang tidak terdaftar semakin kuat sejak disahkannya UU No. 10 Tahun 2016 tentang Pilkada dan UU Pemilu yang mengatur persyaratan pemilih bagi setiap warga dalam menggunakan hak pilih, hasil dari penguatan sistem sidalih ini akan menghasilkan DPT yang benar-benar valid dan faktual.

\section{KESIMPULAN}

Pemilihan Umum (Pemilu) sebagai pilar demokrasi, keberhasilan Pemilu sangat dipengaruhi oleh seberapa besar tingkat kesadaran politik warga negara yang bersangkutan. Kesadaran politik ini terefleksi dari seberapa besar partisipasi dan peran masyarakat dalam proses Pemilu, dengan memberikan kesempatan kepada setiap warga negara untuk memberikan suara dukungannya dalam proses penetapan pemerintah baik di eksekutif maupun 
legislatif. Keberadaan Komisi Pemilihan Umum (KPU) sebagai penyelenggara Pemilihan Umum (Pemilu) memiliki nilai strategis yang sangat penting. KPU bertugas menyiapkan instrumen untuk Meningkatkan partisipasi dalam Pemilu demi terwujudnya Indonesia yang demokratis.

Penetapan DPT Oleh Komisi Pemilihan Umum (KPU) memberikan hak seluas-luasnya kepada masyarakat untuk dapat memiliki hak yang sama, dengan demikian DPT yang ditetapkan oleh KPU dapat mencerminkan kedaulatan rakyat dalam pelaksanaan pemilu yang demokratis, karena DPT itu berbanding dengan semakin sedikit pemilih yang terdaftar di DPT, maka semakin rendah tingkat demokrasinya, sebaliknya semakin tinggi angka masyarakat yang terdaftar di DPT, maka semakin tinggi pula derajat demokrasinya suatu Negara.

Komisi pemilihan umum (KPU) dalam meningkatkan partisipasi pemilih harus mampu mensosialisasikan kepada masyarakat pemilih berkaitan dengan pemilu diantaranya yaitu, Manfaat Pemilu, Nama-nama peserta pemilu, ajakan memberikan suara pada saat pemungutan suara, tata cara pemilu, jadwal pemilu,khususnya pada tahap kampanye, tata cara pencoblosan dan pengumuman hasil penghitungan suara. Agar pesan-pesan yang diberikan pada kegiatan sosialisasi pemilu mudah diterima oleh masyarakat, dalam meningkatkan partisipasi pemilih KPU perlu mendesain dengan menarik, informatif, sederhana dan mudah dipahami agar penyelenngaraan pemilu menjadi lebih baik.

Penetapan pemilih (DPT) oleh Komisi pemilihan umum (KPU) tujuannya adalah untuk menciptakan pemilu yang demokratis. Masih banyaknya warga yang tidak terdaftar di DPT bisa berakibat pada hilangnya hak untuk memilih. Dalam hal ini KPU sebagai penyelenggara Pemilu harus membuat instrumen Daftar Pemilih Khusus (DPK) dan Daftar Pemilih Khusus 
62 | Penetapan Daftar Pemilih Oleh Komisi Pemilihan Umum Sebagai Wujud Penguatan Sistem Demokrasi

Tambahan (DPKTb) untuk mem-back up warga negara yang tidak dalam DPT atau daftar pemilih tambahan (DPTb)

\section{DAFTAR PUSTAKA}

Dian Bakti Setiawan, Pemberhentian Kepala Daerah, Mekanisme Pemberhentiannya Menurut Sistem Pemerintahan Di Indonesia, Rajawali Pers, Depok, 2017.

Ibnu Tricahyono, Reformasi Pemilu Menuju Pemisahan Pemisahan Pemilu Nasinal Dan Lokal, In trans Publishing, Malang, 2019.

Muhadan Labolo, Teguh Ilham, Partai Politik Dan Sistem Pemilihan Umum Di Indonesia" Teori, Konsep Dan Isu Strategis, Rajawali Press, Jakarta. 2017.

Zainal Arifin Hoesein, Arifudin, Penetapan Sistem Pemilihan Umum, Rajawali Pers. Depok, 2017.

Dwi Sulisworo, Tri Wahyuningsi, dkk, Demokrasi, Program Studi Pendidikan Kewarganegaraan, Hibah Pembelajaran Non Konvensional, 2012.

Moh Kusnadi, Harmaily Ibrahim, Hukum Tata Negara Indonesia, Sinar Bakti Jakarta, 1988.

Pataniari Siahan, Politik Hukum Pembentukan Undang Undang Pasca Amandemen UUD 1945, Konpress, Jakarta, 2012.

William Liddle, Revolusi Demokratisasi di Indonesia dari Luar, Nalar, Freedom Institute, Jakarta 2015

M. Taufik, Meogono, Moralitas Penegak Hukum dan Advokat Profesi Sampah, JP Books, Surabaya, 2007 
Johnny Ibrahim, Teory Dan Metodologi Penelitian Hukum Norma, Bayumedia Publising. Malang, 2019

Robiyan arifin, Problematika Hukum Dalam Pemilukada, Pena salsabila Putra Pratama. Surabaya, 2013

Nanang nugraha, Model Kerwenangan Wakil Kepala Daerah Dalam

Pemerintahan Daera, Refika Aditama, Bandung, 2013

Adnan Buyung Nasution, Perlindungan dan Jaminan Hak Azasi Manusia, (Politik dan HAM), Pustaka Delta Press, Jakarta 2014

Firmanzah, Persaingan Legitimasi Kekuasaan, Dan Marketing Politik,

Pembelajaran Pemilu 2009, Yayasan Pustaka Obor Indonesia, Jakarta, 2010 Zubakhrum, Pilkada Serentak Penguatan Demokrasi Di Indonesi, Pustaka Kemang, Jakarta 2016.

Kansil, christine, Hukum Tatanegara Republik Indonesi, Rineka Cipta, Jakarta, 2000

Ibramsyah Amirudin, Kedudukan KPU Dalam Struktur Ketatanegaraan Republik Indonesia Pasca Amandemen UUD 1945, Laksbang Mediatama, Yogyakarta, 2008

Indra Pahlevi, Sistem pemilu di indonesia antara Proporsional dan mayoritarian, P3DI dan Azza Grafika, Jakarta, 2015

Eko Handoyo, Ngabiyanto, dkk, Pemilu Untuk Pemula, Sistem dan Peserta Pemilihan Umum, Universitas Negeri Semarang, Semarang, 2013 Fadli Ramadhanil, Veri Junaidi, Dkk, Desain Partisipasi Masyarakat Dalam Pemantauan Pemilu, Kemitaraan Partnership dan Perludem, Jakarta 2015 Arif rahman Hakim, Purwanto, Ruslan Hidayat, Inovasi Pemilu, Mengatasi Tantangan Memanfaatkan Peluang, Komisi Pemilihan Umum, Jakarta, 2017 
Masyukurudin Hafidz, Usep Hasan Sadikin, Penyelenggaraan Pilkada Serentak 2015-2017, Komisi Pemilihan Umum, Jakarta, 2017 Jeff Heyness, Demokrasi Dan Masyarakat Sipil Di Dunia Ketiga, Obor, Jakarta , 2000

Arbi Sanit, Perwakilan Politik Di Indonesia, Rajawali, Jakarta, 1985

Peter Mahmud Marzuki, Penelitian Hukum, Kencana Prenada Media Group, Jakarta 2013

Jimly Asshiddiqie, Pengantar Ilmu Hukum Tatanegara Jilid II, Sekretariat Jenderal dan Kepaniteraan MK RI, Jakarta 2016

Mukthie Fadjar, Pemilu, Perseliban hasil Pemilu dan Demokrasi, Setara Press, Malang 2013.

Lukman Hakim, Kerangka Politik Hukum Di Indonesia,( Membangun Negara Hukum yang Bermartabat), Setara Press, Malang 2013.

Bambang Sugianto, Analisis Yuridis Penerapan Dan Bentuk-Bentuk Tindak Pidana Pemilu Menurut Undang-Undang Nomor 7 Tahun 2017, Jurnal Al'adl, Volume IX Nomor 3 Desember, 2017.

Faisal Rahman, Meneropong Integritas Penyelenggara Pemilu, Jurnal Ide, KPU, Volume 13, November 2016

Sun Fatayati, Relevansi Asas-Asas Pemilu Sebagai Upaya Menciptakan Pemilu Yang Demokratis Dan Berintegritas, Jurnal Relevansi, Volume 28, Januari, 2017.

Prayudi, Mengapa Masalah DPT Terus Terjadi?, Jurnal Info Singkat, PusaPenelitian, Badan Keahlian DPR RI, volume x, september, 2018. Demas Brian Wicaksono, Pemilihan Kepala Daerah Berdasar Atas UndangUndang Dasar Republik Indonesia Tahun 1945, Program studi Magister Ilmu Hukum, Universitas Jember, 2014 
Daud M Liando, Pemilu dan Partisipasi Politik Masyarakat, Jurnal LPPM Bidang Ekososbudkum, Volume 3 No 2, Oktober 2016.

Iwan Mahendra, Implementasi Kebijakan Pendataan Pemilib Dalam

Pemilihan Umum Kepala Daerah Kota Malang 2013, Jurnal Reformasi,

Volume 8, Nomor 1, 2018.

Dudi Warsudin, Optimalisasi Kpu Dalam Peningkatan Partisipasi

Masyarakat Dalam Pemilu, Jurnal Ilmu Hukum Ligitasi, Volume 14, No 2

Oktober 1995

Iwan Rachmat Soetijono, Kerwenangan Menyusun Daftar Pemilih Secara

Otonom Oleh Komisi Pemiliban Umum, Majalah Ilmiah, Volume 1, Fakultas Hukum Universitas Jember, Jember, 2010

Amsori, Penyuluhan Pendidikan Politik Bagi Pemilih Pemula Guna Meningkatkan Partisipasi Hak Pilih Pada Pemilihan Gubernur Dki Jakarta Tahun 2017, Jounal of empowerment, volume 1, juni 2017

Sarbaini, Demokratisasi Dan Kebebasan Memilib Warga Negara Dalam

Pemiliban Umum, Jurnal Inovatif, Volume VIII, No 1 Januari 2017

Khairul Fahmi, Prinsip Kedaulatan Rakyat Dalam Penentuan Sistem

Pemilihan Umum Anggota Legislati, Jurnal Konstitusi, Volume 7, No 3, Juni 2010

Maslekah Pratama Putri, Peran Komisi Pemilihan Umum Dalam Sosialisasi Pemilu sebagai upaya Untuk Meningkatkan Partisipasi Politik Masyarakat

Pada Pemilu Presiden 2014 di Kalimantan Timu, Jurnal Ilmu Komunikasi, Volume 30, April 2016

Aminah, Analisis Penerapan Sistem Proposional Dan Sistem Distrik Dalam Pemilihan Umum Untuk Penyedederhanaan Sistem Kepartaian Di Indonesia Ditinjau Dari Asas Negara Hukum, Jurnal Yustisia Volume 1, Nomor 2, Agustus 2012 
Undang-Undang Dasar Negara Republik Indonesia Tahun 1945 Undang-Undang Nomor 7 tahun 2017 Tentang Pemilihan Pemilu (Lembaran Negara Republik Indonesia Tahun 2017 Nomor 182 Peraturan Komisi Pemilihan Umum Nomor 37 Tahun 2018 Tentang Penyusuan Daftar Pemilih dalam Negeri dalam penyelengaraan pemilihan umum.

PKPU No 10 tahun 2018 tentang Sosialisasi, Pendidikan Pemilih Dan Partisipasi Masyarakat Dalam Penyelenggaraan Pemilihan Umum. Putusan Mahkamah Konstitusi Nomor: 102/PUU-VII/2009 tentang pemilihan umum Presiden dan Wakil Presiden Putusan Mahkamah Konstitusi Nomor: 135/PUU-XII/2015 Tentang Perubahan atas Undang-undang Nomor 1 Tahun 2015 tentang penetapan peraturanPemerintah Pengganti Undang-undang Nomor 1 Tahun 2014 Tentang Pemilihan Gubernur, Bupati dan Wali Kota https://www.nasional.tempo.co/amp/KPU diminta tetap mendata pemilih meski telah tetapkan dpt.

Putusan mahkamah konstitusi Nomor : 102/PUU-VII/2009, Bagian https://diy.kpu.go.id/web/2016/12/19/pengertian-fungsi-dan-sistempemilihan-umum/ https://kolom.tempo.co/read/1179936/prospek-partisipasi-pemilih https://kbbi.kemdikbud.go.id/entri/pemilihan\%20umum Indek demokrasi indonesia yang di terbitkan atas kerjasama bapenas, kementerian dalam negeri, BPS dan UNDP, 2013 